\title{
Urban Ecology in Cape Town: South African Comparisons and Reflections
}

\author{
$\underline{\text { Sarel S. Cilliers }}^{1}$ and Stefan J. Siebert ${ }^{1}$
}

\begin{abstract}
Little urban ecological research has been done in South Africa. The papers in the Ecology and Society special feature Urban Ecological and Social-Ecological Research in the City of Cape Town make, therefore, an important contribution to the development of urban ecology locally and globally. Different approaches have been used in the study of urban ecology of different urban areas in South Africa. Cape Town is situated in a biodiversity hotspot and is the only South African city which includes a national park. As a result the urban ecological studies were mainly driven by urban nature conservation concerns. In other cities such as Durban, open space planning and environmental management were the major issues which focused ecological studies on urban areas whereas other studies of urban areas in the Eastern Cape and North-West provinces included private and public open spaces and man-made habitats. We reflect on the Cape Town studies in a South African context and highlight conservation of biodiversity, protection of ecosystem services, management of control measures, and the conflict between humans and nature. A brief synthesis has also been given of South African urban ecological research in general.
\end{abstract}

Key Words: urban ecology; South Africa; urban nature conservation; urban environmental management

\section{INTRODUCTION}

The term "urban ecology" is not often used in South African scientific literature. When used, it is usually not well defined and refers to various actions following different approaches. The most popular definition for urban ecology in natural sciences implies the study of the interactions between biotic and abiotic in the urban environment, using similar approaches and techniques as in the natural environment (Sukopp 1998). This definition is, however, too generic and the definition of Marzluff et al. (2008) seems to be the most appropriate one if the human aspect and applied nature of modern urban ecological studies in South Africa, are included. They described urban ecology as an "emerging interdisciplinary field that aims to understand how humans and ecological processes can coexist in human-dominated systems and help societies with their efforts to become more sustainable." In our view the term transdisciplinary should be added to this definition. Fry et al. (2007) distinguished between transdisicplinary and interdisciplinary research in terms of the integration of nonacademic participants such as managers and the public with academic researchers from different nonrelated disciplines, in an endeavor to develop new knowledge and theory in answering common research questions. For a comprehensive international overview of the history of Urban Ecology from an ecological perspective, see McDonnell (2011) and from a landscape ecological perspective, see $\mathrm{Wu}$ (2008).

We reflect on the studies published in the Ecology and Society special feature Urban Ecological and Social-Ecological Research in the City of Cape Town in a South African context. From literature it is clear that ecological studies in South African urban areas have followed different approaches and evolved along different lines. Urban ecology in Cape Town was first and foremost driven by the need to conserve the unique biodiversity and natural areas in and around the city (Rebelo et al. 2011, Holmes et al. 2012). In contrast, urban environmental management and the protection of key environmental goods and services provided by urban open spaces were the most important drivers in Durban (Roberts 2001, Roberts et al. 2005). Ecological studies in small and medium-sized cities in the Eastern Cape focused on public green spaces like parks, school grounds, sport fields and street trees (McConnachie and Shackleton 2010, McConnachie et al. 2008, Kuruneri-Chitepo and Shackleton 2011). Patterns of the entire urban green infrastructure and the processes that drive them (Cilliers et al. 2008, Davoren 2009, Cilliers and Siebert 2011, Molebatsi 2011), including private gardens (Lubbe et al. 2010,2011), formed the focus of urban ecological studies in the North-West Province.

Papers dealing with the urban ecology of Cape Town can be classified in different ways, but all efforts could be hampered by the large amount of overlap between the main ideas in all the papers. Nonetheless, an attempt was made to group the papers (Table 1), and to generate a structure for logical discussion. The two main focus areas identified from the Cape Town papers were conservation with focus on biodiversity and ecosystem services and management which includes papers on management of control measures and management of the human-nature divide (Table 1). Each of these main groups of papers will be discussed and compared with studies from the rest of South Africa. It is not our aim to give an elaborate overview of all urban ecological studies in South Africa and to refer to all available literature. We will mainly focus on journal papers, book chapters, and to a certain extent

${ }^{1}$ North-West University (Potch) 
Table 1. Main themes of the urban ecology papers focusing on Cape Town

\begin{tabular}{|c|c|}
\hline Conservation & Management \\
\hline $\begin{array}{l}\text { Biodiversity } \\
\text { - Biodiversity hotspot, threats, systematic conservation planning - } \\
\text { Holmes et al. } 2012 \text {. } \\
\text { - Threats of urbanization to biodiversity: harvesting for informal } \\
\text { trades - Petersen et al. } 2012 \text {. } \\
\text { Threat of biotic homogenization: sensitivity of an important } \\
\text { pollinator - Pauw and Louw } 2012 \text {. }\end{array}$ & $\begin{array}{l}\text { Control measures } \\
\text { - Fire in the Table Mountain National Park (World Heritage Site) - } \\
\text { Van Wilgen et al. } 2012 \text {. } \\
\text { - Alien invasive plant control in the Table Mountain National Park } \\
\text { (World Heritage Site) - Van Wilgen 2012. }\end{array}$ \\
\hline $\begin{array}{l}\text { Ecosystem services } \\
\text { - Shifting of important ecosystem services over time: historical } \\
\text { development - Anderson and O'Farrell } 2012 \text {. } \\
\text { - Rapid ecosystem service assessment based on transformation of } \\
\text { vegetation cover - O'Farrell et al. } 2012 \text {. }\end{array}$ & $\begin{array}{l}\text { Human-nature divide } \\
\text { - Co-management: unique vegetation types on the city fringes } \\
\text { (Cape Flats) - Graham and Ernstson } 2012 \text {. } \\
\text { - Conflict management: baboons in the Cape Peninsula - Hoffman } \\
\text { and O'Riain 2012. }\end{array}$ \\
\hline
\end{tabular}

unpublished dissertations and reports. We acknowledge that there is a wealth of grey literature, including many unpublished reports, websites, and even newspaper coverage on different aspects of urban ecology in many South African urban areas.

\section{CONSERVATION OF BIODIVERSITY AND ECOSYSTEM SERVICES}

\section{Biodiversity}

The city of Cape Town is unique in terms of its high biodiversity, including a large diversity of endemic and endangered vegetation types and species, and should therefore be conserved (Holmes et al. 2012). Holmes et al. (2012) put the conservation importance of Cape Town in perspective, both locally and globally: “....nearly half of the country's most threatened ecosystems occur in Cape Town." and "Cape Town's Red List plant figures are higher than most countries in the world and to our knowledge exceed those listed for any other city." Due to the high conservation status of the Cape Floristic Region, extensive research on different aspects of the more natural areas in this region has been conducted.

The new millennium saw the coming of age of various research initiatives to establish a systematic conservation plan for the Cape Floristic region as one of the global biodiversity hotspots (Younge and Fowkes 2003, Cowling and Pressey 2003). The City of Cape Town lies within this hotspot and hence its land area was incorporated as part of the conservation plan. This provided a biodiversity theme to the early momentum of urban ecology in Cape Town. The city, therefore, formed part of several studies to identify areas of special conservation concern (Cowling et al. 2003, Rouget et al. 2003), which has recently culminated in Table Mountain being declared a National Park and granted World Heritage Status (Holmes et al. 2012, Van Wilgen et al. 2012). Urban ecological research in Cape Town is specifically addressing urbanization as one of the major challenges to conservation (Rebelo et al. 2011). The biodiversity studies of an urban ecological nature which are featured in the special feature, recognize this problem and consider means whereby management authorities and the public could be involved to bridge the researchimplementation gap in conservation planning by moving away from pure academic exercises (Knight et al. 2008) to applied management actions (Gelderblom et al. 2003). The development of this approach is best illustrated by the removal of alien vegetation within the City of Cape Town and the rehabilitation of these lands to restore its biodiversity (Pryke and Samways 2009). It is obvious, therefore, that the history of conservation planning in the Cape Floristic Region has empowered Cape Town to become the leading municipality in South Africa in terms of protection of representative areas of terrestrial biodiversity in the city (Holmes et al. 2012). It can therefore be assumed that biodiversity issues formed a solid basis for the development of urban ecological research in Cape Town.

The biodiversity of the natural areas surrounding the other urban areas in South Africa has not been studied to the same extent as in Cape Town. While Cape Town chose to engage in systematic conservation planning, other urban areas were only starting to document their biodiversity due to a growing awareness that detailed ecological data was required for the implementation of conservation-orientated planning and management of urban open spaces (Cilliers et al. 2004). There are several examples of descriptive vegetation studies aiming towards classification of plant communities in several urban areas in South Africa. The vegetation of natural areas surrounding cities and fragmented areas inside cities have been described in Durban, KwaZulu-Natal (Roberts 1993), Potchefstroom, North-West Province (Cilliers et al. 1998, 1999), Bloemfontein, Free State (Dingaan et al. 2001), Johannesburg and Pretoria, Gauteng (Grobler et al. 2002, 2006) and Nelspruit, Mpumalanga (Wilken 2007). What distinguishes these studies from the initial vegetation studies in Cape Town are the description of vegetation of disturbed 
and degraded areas as well. Additionally, in some of these areas the vegetation of intensively managed sites such as parks and pavements as well as road verges and railway embankments have been described (Cilliers and Bredenkamp 1998, 1999, 2000).

However, all these descriptive studies will only be of academic value if the data is not presented in an understandable format to local authorities for implementation in planning and management of urban open spaces (Cilliers et al. 2004). The development and implementation of a biodiversity plan for Cape Town is a good example of systematic conservation planning in action, where the data can actually be acted on by the local government. The biodiversity network of Cape Town includes existing conservation areas, and other areas that need to be conserved, namely critical biodiversity areas and critical ecological support areas (Holmes et al. 2012). The conservation plan further sets realistic biodiversity targets, which were determined after consultation with various stakeholders (Holmes et al. 2012). It was also determined that the scale on which conservation assessments were done was scientifically sound as the biodiversity of the mentioned areas are highly threatened and irreplaceable and more refinement of the biodiversity of the natural areas in the city was not a priority (Holmes et al. 2012). The development of an implementation strategy in which key stakeholders would be involved, has a much higher priority (Holmes et al. 2012). The city of Cape Town is fortunate, according to Holmes et al. (2012) in that they have a "dedicated biodiversity team" that is working hard to bridge the gap, as mentioned before, between scientific knowledge on conservation and actions at ground level. Descriptive vegetation studies in Durban formed a solid base for open space planning and it became the first of several South African municipalities to implement a Metropolitan Open Space System (MOSS) approach in urban nature conservation (Seppings et al. 1995, Cilliers et al. 2004). The aim of this approach was to shift the focus from conserving individual species to protecting functional plant communities, maintaining maximum sustainable biotic diversity and minimizing extinction (Roberts 1993, Seppings et al. 1995) by following a biogeographical perspective along the lines of the island biogeography theory (Poynton and Roberts 1985). The city of Durban does not have a systematic conservation plan dedicated to the city as in Cape Town, but the city is included in the KwaZulu-Natal provincial conservation plan; which was compared by Knight et al. (2006) to other studies on systematic conservation planning in South Africa.

The vegetation studies in Potchefstroom formed the basis of a comprehensive urban biotope mapping exercise, based on approaches followed in German cities (Sukopp and Weiler 1988). In the Potchefstroom study all the natural, semi-natural and man-made biotopes were described and mapped following a hierarchical classification approach, upon which the biotopes were evaluated in terms of their "worthiness of protection" based on a set of criteria (Cilliers et al. 2004). All the information was spatially explicit and was successfully transferred to the Integrated Development Plan (IDP) of the Potchefstroom Municipality (Drewes and Cilliers 2004). (See Cilliers et al. [2011] for a discussion of the resolved and unresolved policy issues in the global South, and a focus on spatial planning in South Africa, and in particular how the integrated development plans [IDP's] and spatial development frameworks [SDF's] were developed.) Applying the urban biotope mapping approach is labor and cost intensive and therefore, larger cities in South Africa opted for a systematic conservation planning approach in which the conservation of representative areas is promoted, as discussed earlier (Holmes et al. 2012).

\section{Threats to biodiversity}

The pressure on the local government of Cape Town to conserve this biodiversity hotspot, which also has the highest per capita population growth rate of all South African cities (Holmes et al. 2012) is immense and a highly complex issue. Increased urbanization created a large threat to the unique biodiversity mainly due to habitat transformation and alien invasive plants (Holmes et al. 2012). Petersen et al. (2012) reported on another threat, the harvesting of native fauna and flora species for the informal trade, which occurs at higher levels than was previously thought. They questioned the ecological sustainability of these actions and stated that "indiscriminate harvesting and biodiversity substitution" are leading to cases of "resource stripping" in protected areas. The demand for products such as traditional medicine, food, building material, and firewood have increased excessively, mainly due to the migration of millions of rural South Africans to cities after 1994, and forms the backbone of an unregulated, unregistered economic enterprise in Cape Town (Petersen et al. 2012). The number of plant species used for medicinal purposes in Cape Town were compared by Petersen et al. (2012) to those in several other areas in South Africa, although these studies did not only focus on cities, but also included rural settlements with a very high demand for medicinal plants.

Specialists are highly sensitive to ecosystem change, while generalists are better adapted to the urban environment and Pauw and Louw (2012) indicate that there is a decline in specialist species, such as the Malachite sunbird, in urban areas. This could lead to biotic homogenization which may threaten native biodiversity (as described by McKinney and Lockwood 1999), both in terms of bird and plant species. A study by Van Rensburg et al. (2009) along an urban gradient in Pretoria, Gauteng supports the idea of biotic homogenization in urban areas. They, however, also found that bird species richness was significantly higher in the urban than in the semi-natural areas on the urban fringe, but alien species abundances were the highest. 
Pauw and Louw (2012) suggested that the planting (in private and public open spaces) of indigenous plant species (with longtubed flowers) could restore the nectarivorous bird guild in Cape Town. They did, however, also ask the relevant question of whether the gene pool of wild plant populations would not be contaminated by closely related garden plants. This problem needs to be addressed by careful research on the preferred origin of garden plants. Avlonitis (2011) mentioned the importance of social interventions in terms of ecological integrity of previously degraded sites, which could also include gardens. Restoring more degraded urban fragments would increase connectivity between natural areas (Avlonitis 2011). On the other hand, Dures and Cumming (2010) stated that the conservation of high quality habitats is more important than the extension of current habitat networks with poor quality. The use of local indigenous species, subspecies, and ecotypes should be promoted through extensive restoration programs to counter the negative effects of biotic homogenization (Holmes et al. 2012). Habitat quality can also be ensured by addressing the homogenizing influences of invasive alien species (Dures and Cumming 2010).

Several studies in private domestic gardens in deep rural (Molebatsi 2011), rural (Davoren 2009), peri-urban, and urban areas (Lubbe 2011, Lubbe et al. 2010, 2011) in the North-West Province have shown the value of private gardens and the importance of studying their biodiversity and ecology, and indicate that they do not necessarily promote biotic homogenization. There is globally a growing realization of the importance of private gardens as part of the entire urban green infrastructure. Firstly due to the large surface area they cover in every city all over the world, secondly the linkage between themselves and other green areas, and thirdly, their contribution to urban biodiversity that forms the basis of several ecosystem services, as indicated in several papers, discussed by Cilliers et al. (2012). Urban domestic garden studies are extremely rare in South Africa, and this is not only ascribable to problems with accessibility, the dynamic nature of gardens, and the fact that they form unregulated habitats (Gaston et al. 2005a, Mathieu et al. 2007), but is also due to the perception that garden plants are mainly exotic and therefore of no ecological value. Gardens have, however, a great potential to maintain indigenous diversity and threatened species, even though they also contain alien species with the potential to become invasive (Lubbe et al. 2011). Both are good reasons to study urban domestic gardens. In the Tlokwe Municipal area domestic gardens have seven times more alien plant species than any of the other land-use types (Lubbe et al. 2010). Gardens ranked below natural areas in indigenous diversity but included more than double that of wetlands, parks, vacant lots, road verges, and railway reserves (Lubbe et al. 2010).

A general shift from urban nature conservation approaches towards the inclusion of humans as important ecological agents in the urban environment has been proposed in several studies, both in South Africa and abroad (Cilliers et al. 2004). Inclusion of social aspects in urban ecological studies has been addressed in different ways in Cape Town, Durban, and urban areas in the North-West Province (Cilliers 2010). Social aspects are nowhere more appropriate to study than in the urban domestic gardens of South African cities with their steep socio-economic gradients (Lubbe et al. 2010). Furthermore, garden studies of the Batswana people in the North-West Province have indicated that gardens form an important Indigenous Knowledge system in deep rural and rural areas but not in peri-urban areas, where the gardens of black ethnic groups have a layout similar to European gardens (Molebatsi et al. 2010). These studies form a good background to further studies in how the use of utilitarian plants (also indigenous plants) could improve the livelihood of poor communities. Garden studies from more cities in South Africa (also in Cape Town) would dramatically increase our knowledge about the social and ecological aspects of the entire urban green infrastructure. Urban domestic gardens have the ability to provide ecosystem goods and services, wildlife habitat, and corridors between semi-natural areas (Savard et al. 2000, Davies et al. 2009). From a financial point of view, the garden fraction of the city engulfs large sums of money in the form of management costs (Gaston et al. 2005b). However, gardens can also generously contribute to biodiversity enhancement in urban areas if resources are applied correctly. Garden floras are extremely important as plants provide food and habitat prospects for other taxa (Smith et al. 2006a, b, Pauw and Louw 2012). The high species richness, as well as the extent of private gardens in cities, provides many opportunities for conservation by the general public.

\section{Ecosystem services}

Even in a city like Cape Town that is situated in a biodiversity hotspot, all stakeholders do not regard its unique biodiversity as reason enough to qualify the conservation of the remaining natural areas in and around the city. An additional approach which shows the importance of biodiversity to human wellbeing is the provision of numerous goods and services by natural ecosystems (O'Farrell et al. 2012). A historical analysis of the development of Cape Town from an ecological perspective has shown, amongst other aspects, the shift in emphasis of different ecosystem services, as certain ecological processes were either conserved or exploited (Andersen and O'Farrell 2012). Spatial models were developed to show the effect of three different land transformation scenarios on nine different ecosystem services classified in four themes, namely agricultural provision, water run-off regulation, ground water, and coastal zone protection (O'Farrell et al. 2012). Basic provisioning services such as water, grazing, and firewood have shifted beyond the city boundary, which is not a critical issue (Andersen and O'Farrell 2012, O'Farrell et al. 2012). The fact that regulatory services such as coastal zone 
protection and flood mitigation were shown to deteriorate significantly is, however, critical to urban sustainability (O'Farrell et al. 2012). The only way to deal with this critical issue is to incorporate the mentioned spatial models in city planning which will most likely require trade-offs. Although the ecosystem service approach is valuable to sensitize various stakeholders about the value of biodiversity (Roberts et al. 2005), the approach of selecting and protecting only those areas with the highest values of ecosystem services will be detrimental from a biodiversity perspective, according to O'Farrell et al. (2012). They proposed, therefore, that biodiversity in a hotspot such as Cape Town should override ecosystem services, as rationale for conservation, in certain cases.

Two other South African studies contradicted the above mentioned proposal, to a certain extent, in that they proposed that conservation should be based on priority areas in terms of provision of ecosystem goods and services (EGS). The more recent of the two is the assessment of priority areas for ecosystem service management in South African grasslands, not focusing on urban areas as such (Egoh et al. 2011), and the second study is the earlier application of the EGS and resource economics approach in Durban (Roberts et al. 2005). Durban, influenced by international ecosystem service research, and driven by issues such as a global focus on sustainable development and a necessity to address the basic needs of all urban residents, implemented the EGS approach as early as 1994 (Roberts et al. 2005). In Durban, the emphasis clearly shifted from biodiversity conservation towards EGS provisioning by the Durban metropolitan open space system (D'MOSS) network (Roberts et al. 2005). Durban relied heavily on international research (Costanza et al. 1997) to select the ecosystem service types. Although more ecosystem services were assessed than in Cape Town (17 vs. 9), those in Durban were not as specific, and included general aspects such as food production, gas regulation, climate regulation and water supply (Roberts et al. 2005). The EGS of a variety of open-space cover types were evaluated and it was determined that floodplains, wetlands and forests hold the potential to supply a wider range of services than any of the other open spaces. They did not only focus on the supply of ecosystem services by urban open spaces, but the demand for these services was also determined (Roberts et al. 2005). Communities without access to high levels of utility services or infrastructure are those with the highest demand on ecosystem services to fulfill their basic needs (Roberts et al. 2005).

Additionally, the monetary values of the different ecosystem services were determined for different land-cover types in Durban using the average global values as determined by Costanza et al. (1997). The replacement value of all the EGS delivered by the Durban open spaces was estimated at R 3.1 billion per annum, excluding the value of tourism in Durban
(R 3.3 billion). It was acknowledged that although resource economics is a useful tool, it still has uncertainties that need to be addressed, as some EGS are intangible and difficult to quantify in economic terms (Roberts et al. 2005). Some of these problems were addressed in Cape Town but were not discussed in any of the contributions in this feature. An economic valuation of those EGS regarded as the most important by decision makers in the city of Cape Town (tourism, recreation, aesthetics and sense of place, space for biota, water purification and waste treatment, and natural hazard regulation) was completed by De Wit et al. (2009) focusing on financial decision-makers to invest in the city's urban natural assets. The economic valuation of these EGS seem to be more objective than in Durban, in that four economic valuation techniques were used (market prices, shadow prices, direct proxies, or nonmarket methods), individually or in combination (De Wit et al. 2009). The application of these efforts in city management and budget allocation are, however, important challenges that need to be addressed. According to TEEB (2011) the EGS valuation process was integrated into the business plan of Cape Town, but did not influence financial policy and budget allocations towards "green issues". This is probably still due to a lack of understanding of the value of the city's natural assets and competing demands with a strong bias towards service delivery rather than the protection of ecosystem services.

\section{CONTROL MEASURES AND THE HUMAN-NATURE DIVIDE?}

Several of the papers in the special feature acknowledged the fact that in order to conserve the unique biodiversity in the Cape Town setting of high population density with informal settlements on the urban fringe, several aspects such as environmental control measures (fire and plant invasions) and conflict between humans and nature (the human-nature divide) need to be managed. Although these two aspects of management are separated in Table 1, they will be discussed collectively, because control measures often highlight the division between humans and nature. The challenge is to integrate ecological, conservational, social, and economical issues into a sound management plan which incorporates the entire city, not only the natural areas with their unique biodiversity. In our view the Cape Town studies are still lacking in this regard, but so are most published urban ecological studies in South Africa. One exception is an earlier study from the Lotus River in Cape Town (Grobicki 2001) which reported on an integrated approach to address urban catchment management. This is an example of a participatory approach in terms of data-gathering, information sharing and management, through a Catchment Committee which included key stakeholders that could participate in decisionmaking and the implementation of recommendations. In the study, physical-chemical, microbiological, macro-invertebrate, and vegetation information were integrated with demographic, 
socio-economic, and hydro-geological information within a GIS platform (Grobicki 2001). This integrated approach serves as a good example for catchment management in other urban areas in South Africa. Environmental management efforts in Durban (Roberts 2008, 2010, Roberts et al. 2011, Roberts and Diederichs 2002), that will be discussed later, also aimed to follow an integrated approach.

As indicated earlier, Cape Town is the only city in South Africa that has a National Park within its borders. This is a huge asset but it also creates complexity and conflict unsurpassed by any other city or national park in South Africa. Two of the complex management issues facing the Table Mountain National Park (TMNP) are elaborately discussed by Van Wilgen (2012) and Van Wilgen et al. (2012). The management of the fire-adapted and fire-prone fynbos ecosystem in the TMNP is loaded with conflict, due to the need for prescribed burning to achieve ecological goals versus prevention and suppression of wildfires for the safety of humans on the outer boundary of the Park (Van Wilgen et al. 2012). This requires integration of both ecological and societal aspects in the development of an adaptive fire management plan, because the effects of fire regime changes are not well understood. Additionally, the fire management plan of the Park needs to be broadened to also include the city and surrounding areas, which is a major challenge, as safety will be the primary goal and not biodiversity conservation (Van Wilgen et al. 2012). Although fire is always a safety and health hazard in all South African cities which contain fragmented natural areas, or natural and conserved areas on the urban fringes, especially in the Grassland and Savanna biomes (fire forms an important driver in the maintenance and conservation of African savanna ecosystems [Govender et al. 2006]), no literature explicitly focusing on fire management in urban areas exist for the rest of South Africa. Cilliers et al. (2008) mentioned the importance of removal of biomass in grasslands in cities through burning or mowing and acknowledged that burning in urban areas requires careful planning and management.

Another complex issue in TMNP management is the clearing of alien invasive species, including trees that are of economic importance in plantation forestry. This issue has drawn quite a lot of reaction from the general public, ranging from acceptance to extreme criticism in the local press. Van Wilgen (2012) presents an excellent example of how to deal with public perceptions, often misinformed, that alien plants are still valuable in conservation areas. Some of the perceptions (e.g. high tree cover increases rainfall) can be easily countered based on facts and scientific interpretations, while other concerns (e.g. trees sequester carbon) have some validity and are addressed as trade-offs, where the negative impacts exceed the benefits (Van Wilgen 2012). The most difficult perceptions to address are those from an aesthetic or value-driven basis, and the only way to deal with those are in terms of a global responsibility to protect the native ecosystems, as TMNP is a declared World Heritage Site (Van Wilgen 2012). Dealing with the mentioned concerns of the public in the local press also implies some sort of environmental education and "promotes awareness of the problem of invasive alien plants, and the benefits of their control" (Van Wilgen 2012). In terms of the rest of South Africa, the same arguments used for TMNP would not always be valid to warrant the removal of alien species in cities, even in conservation areas in cities. We observed a gross misconception, especially in terms of the removal of eucalyptus plantations (mainly Eucalyptus camaldulensis and E. sideroxylon) in urban areas in the NorthWest Province (not a biodiversity hot spot!), with the only "trade-offs", economic exploitation by the "foresters" and excessive erosion (personal observation). Eucalyptus trees in the northern parts of South Africa are extensively used as resting sites for the red listed (vulnerable) hawk, Falco naumannii (Lesser Kestrel) as well as breeding sites for Haliaeetus vocifer (African Fish Eagle) (Henk Bouwman, ornithologist NWU personal communication).

Holmes et al. (2012) referred to several studies in South Africa which have indicated that implementation of conservation principles are only possible if socio-economic issues are taken into consideration with the inclusion of all the relevant stakeholders. A comanagement approach was followed in selected areas in Cape Town as local residents were involved in conservation-orientated management of ecologically important areas (Graham and Ernstson 2012). Although Cape Town is taking a leading role amongst South African municipalities in terms of transdisciplinarity, the engaging of local residents in resource management can be challenging. Interviews with participants of the comanagement program in Macassar dunes have indicated that they regard this exercise as valuable. Education, awareness raising and changing values were regarded as the strong points, but to the contrary there were more negative issues in terms of legitimacy, trust, and commitment (Graham and Ernstson 2012). As will be discussed later, the Durban municipality focused on community and other key stakeholder's participation throughout the development of their environmental management system (Roberts et al. 2002) and more recently the development of a "community ecosystem-based adaptation (EBA)" approach to deal with challenges of climate change (Roberts 2010, Roberts et al. 2011).

Spatial ecology was used to inform human-baboon conflict management in the Cape Peninsula and indicated that landscape management is a preferred management approach to the removal of nuisance troops (Hoffman and O'Riain 2012). The most sustainable ways to manage human-baboon conflict include the conservation of low-lying habitats, increasing the distance between the urban edge and sleepingsites, and preventing access to anthropogenic food sources, forcing baboons to rely on natural food sources which will increase their home ranges, and reduce conflict with humans 
(Hoffman and O'Riain 2012). Urban wildlife management research is quite rare in other South African cities and few published reports were found. The use of feeding stations in decreasing the effects of feral cats on urban wildlife and improving their management on the university grounds of Howard College campus, UKZN in Durban (a registered conservancy), was explored by Tennent and Downs (2008). The results confirmed earlier findings in the UK that the activity patterns of feral cats were not correlated to prey activities, but coincide with the arrival of feeders with food. This seems to be positive in terms of the protection of urban wildlife, but feral cat densities are increasing in response to an abundant supply of food, which will definitely implicate feral cat management (Tennent and Downs 2008).

As was indicated earlier, urban ecology in Durban is driven by an environmental management approach and can be regarded as the leading city in South Africa in this regard (Roberts 2008). In 1994 Durban was the first local government which accepted the challenge to implement Local Agenda 21 (LA21), with the major objective to develop an environmental management system (EMS) after a process of consultation and consensus with their residents (Roberts et al. 2001, Roberts and Diederichs 2002). Agenda 21 is a local action plan that originated from the Earth Summit of the United Nations in Rio in 1992 focusing on the implementation of integrated strategies to address the issue of environmental degradation and the promoting of sustainable development in all countries (Robinson 1993). The EMS aimed to integrate social, economic and ecological concerns in all planning and development actions in Durban (Roberts and Diederichs 2002). From 2002 to 2006 Durban entered into a process to institutionalize climate change which forms part of a South African initiative to respond to the Cities for Climate Protection campaign (CCP) of the International Council for Local Environmental Initiatives (ICLEI) (Roberts 2008). A milestone of this initiative was the completion of a greenhouse gas emissions inventory and the successful implementation of several energy saving projects, which have also lead to the development of a Municipality Climate Protection Program (MCPP) focusing on mainstreaming the climate change debate in Durban (Roberts 2008). Major institutional and resource challenges in motivating local government to realize their responsibility in terms of climate change adaptation were realized. It was also proposed that new links between the biodiversity, climate protection and disaster management functions, are important to address the climate change challenge (Roberts 2010). Realization of the close connection between human and ecological systems has led to the development and application of the concept of "community ecosystem-based adaptation" (EBA) (Roberts et al. 2011). EBA includes biodiversity and EGS as part of a bigger strategy assisting all the stakeholders in adapting to the negative effects of climate change through sustainable management, conservation and the restoration of ecosystems and their services. A lack of research on important issues such as the impact of climate change on urban biodiversity, was also recognized (Roberts et al. 2011).

Although smaller municipalities in South Africa have participated in the CCP program of ICLEI, they lack sufficient baseline data on the ecology of cities (Cilliers 2010, Cilliers et al. 2011) to advise the development of IDP's. As indicated earlier, descriptive studies were conducted in some of these smaller cities, but there was a lack of information on the influence of urbanization (human impacts) on biodiversity and ecological processes. An internationally accepted and widely applied approach, the urbanization gradient approach (McDonnell and Pickett 1990) was used as a framework to study human-induced landscape changes in the North-West Province. The effects of urbanization on the species and functional diversity of plants, arthropods and microorganisms in grasslands were elucidated using an urban-rural gradient approach (Jonas 2007, Du Toit 2009, Janse Van Rensburg 2010). The urban-rural gradient is complex and needs to be quantified in more detail than the traditional use of a linear gradient. Initially the V-I-S approach (Ridd 1995) was followed using the relationship of the percentage vegetation cover (V), impervious surfaces (I) and soil cover (S) of the areas surrounding sample plots. Later a more accurate urbanrural gradient quantification approach developed for Australia (Hahs and McDonnell 2006) was tested and successfully adapted to be used in South Africa (Du Toit 2009). This quantification method followed a landscape ecological approach, and satellite imagery and spatial analysis were used to calculate the values of 12 different measures in two categories, namely landscape metrics, and demographic- and physical variables (Du Toit and Cilliers 2011). The main contribution of this research was in terms of the establishment of a standard set of urbanization measures that can be used in comparing cities of different sizes and in different countries, and in discussing seven important aspects that determine "effective comparative gradient research" (Du Toit and Cilliers 2011).

Comparative urban ecological research between cities is extremely important to improve our understanding of how different components of urbanization influence ecological patterns and processes, with the main goal to increase the outcomes of conservation and the quality of life for all urban residents (Hahs et al. 2009a). Comparing different cities, locally and abroad, will contribute greatly to our knowledge of the ecology of urban areas. This will be enhanced by the heterogeneity of South African urban areas both as a result of unique and diverse vegetation types and unique and complex anthropogenic influences, driven by steep socio-economic gradients. There are other examples of studies along urbanization gradients in South Africa (apart from those in the North-West Province) where the gradients were characterized 
by a single factor, for example the distance from the nearest natural plants pollinated by sunbirds in Cape Town (Pauw and Louw 2012) or by using land-cover classes, namely urban, suburban, and semi-natural within a $250 \mathrm{~m}$ radius around each study site in Pretoria (Van Rensburg et al. 2009). Although these types of studies will not enable comparative studies, it could be useful to determine the effect of urbanization (in general) on species in local context. It should be remembered though, that if the characterization of the gradient is too simplistic, less information will be available to determine which of the variables of urbanization can lead to a better understanding of the causal factors; whereas if distance alone is used to characterize a gradient, it could be related to any number of aspects of urbanization (Hahs et al. 2009a).

Only a few examples of comparative urban ecological research exist in South Africa. Molebatsi et al. (2010) compared species diversity and garden layout of homegardens of the Batswana ethnic group in deep rural, rural, and peri-urban areas in the North-West Province. The results indicated an increase in alien species, decrease in utilitarian species and a change in garden layout from a traditional to a westernized approach. In the Eastern-Cape, McConnachie et al. (2008) and McConnachie and Shackleton (2010) quantified the differences in size and state of public green spaces between different cities and indicated that in lower income areas the green spaces are much smaller with a lower quality, a legacy of separate development of the past. Global comparisons including South African urban areas are even rarer. Hahs et al. (2009b) compared the plant species diversity of Cape Town with 21 other cities to determine plant extinction rates, and Cilliers et al. (2008) reported similar patterns of exotic plant invasions in urban and rural grasslands in South Africa and Australia.

\section{CONCLUSIONS}

Urbanization is a reality and a major threat to prevailing ecosystems and human health and well-being. Urban ecology has much to contribute towards the promotion of sensible development and monitoring of ecosystems, specifically in a global biodiversity hotspot, but also in the broader South African context. Despite the tangible environmental degradation around our cities, very little research is being done in urban environments, (with exceptions the likes of Cape Town and Durban and some urban areas in the North-West Province and Eastern Cape), to identify these problems and to find solutions to solve them.

Urban ecological research requires stakeholder participation and collaboration between researchers in urban ecology towards an in depth understanding of the feats achieved in different urbanization sectors. Prior to this account, the history and future of urban ecology in South Africa has never been considered. It is the "Cinderella" of the natural sciences; maybe because it has it's "feet" also deeply rooted in the social and physical sciences with application value in conservation, spatial planning and environmental management. Urban ecology can therefore be regarded as truly an integrative science. Hopefully this very informative series of papers on the urban ecology of Cape Town and the reflections and comparisons in this paper, will educate scientists about the possibilities that urban ecology holds for their own research specializations and possible applications.

It is evident that urban ecology is driven by different needs and requirements at provincial and even municipal levels. Cape Town's urban ecology was born out of its rich biodiversity, with scientists laying sound foundations for the next phase of urban ecology that will, hopefully, not only be interdisciplinary, but also transdisciplinary. Early indications are, considering the content of the papers in this special feature, that the way forward for urban ecology in Cape Town is indeed so. Although many of the urban ecological studies in South Africa have a strong applied nature, they do contribute to the development of urban ecological theory. These studies accept and address most of the principles that Cadenasso and Pickett (2008) proposed for the development of a successful theory of urban ecosystems, namely that cities should be regarded as ecosystems, spatially heterogeneous, dynamic, containing interacting human and natural processes, and important functional ecological processes.

The further development of urban ecology in South Africa relies heavily on continuation of academic and applied research in the urban areas mentioned in this reflection paper, as well as extension to other urban areas. Different approaches were used and will be used in urban ecological studies in South Africa. Future research should focus on including the entire urban green infrastructure (including private and public open spaces as well as man-made habitats), integration of different academic disciplines (and nonacademic contributions), comparing the ecology between cities locally and globally, studying ecological patterns and the processes (biological, physical and socio-economical) driving them, as well as understanding the mechanisms behind the processes. The study of urban ecosystems in South Africa and elsewhere, should therefore aim to investigate, model and monitor the linkages between ecological and social systems, as explained and summarized by Zipperer et al. (2011) and already attempted for rural areas in South Africa, focusing on a socioecological systems view using the resilience approach (Pollard et al. 2008).

Responses to this article can be read online at: http://www.ecologyandsociety.org/vol17/iss3/art33/ responses/

\section{Acknowledgments:}

This paper is a product of the Urban Ecology CityLab which is part of the CityLab programme of the African Centre for Cities at the University of Cape Town. The African Centre for 
Cities' CityLab programme is funded through the Mistra Urban Futures network (which is funded by Mistra the Foundation for Strategic Environmental Research and the Swedish International Development Cooperation Agency), the Provincial Government of the Western Cape (Department of Human Settlements) and the City of Cape Town.

\section{LITERATURE CITED}

Anderson, P. M. L., and P. J. O'Farrell. 2012. An ecological view of the history of the City of Cape Town. Ecology and Society 17(3):28. http://dx.doi.org/10.5751/ES-04970-170328

Avlonitis, G. 2011. Understanding urban ecology: exploring the ecological integrity of small scale greening interventions in the City of Cape Town. Unpublished Masters Dissertation, University of Cape Town.

Cadenasso, M. L., and S. T. A. Pickett. 2008. Urban principles for ecological landscape design and management: scientific fundamentals. Cities and the Environment 1(2), article 4, htt p://escholarship.bc.edu/cate/vol1/iss2/4.

Cilliers, S. S. 2010. Social aspects of urban biodiversity - an overview. Pages 81-100 in In N. Müller, P. Werner and J. G. Kelsey, editors. Urban biodiversity and design. WileyBlackwell, Oxford. http://dx.doi.org/10.1002/9781444318654. $\underline{\operatorname{ch} 4}$

Cilliers, S. S., and G. J. Bredenkamp. 1998. Vegetation analysis of railway reserves in the Potchefstroom Municipal Area, North-West Province, South Africa. South African Journal of Botany 64(5):271-280.

Cilliers, S. S., and G. J. Bredenkamp. 1999. Analysis of the spontaneous vegetation of intensively managed urban open spaces in the Potchefstroom Municipal Area, North-West Province, South Africa. South African Journal of Botany 65 (1):59-68.

Cilliers, S. S., and G. J. Bredenkamp, 2000. Vegetation of roadside verges on an urbanization gradient in Potchefstroom, South Africa. Landscape and Urban Planning 46:217-239. http://dx.doi.org/10.1016/S0169-2046(99)00057-2

Cilliers, S. S., and S. J. Siebert. 2011. Urban flora and vegetation: patterns and processes. Pages $148-158$ in J. Niëmela, J. Breuste, T. Elmqvist, G. Guntenspergen, P. James and N. E. McIntyre, editors. Urban ecology: Patterns, Processes and Applications. Oxford University Press, Oxford.

Cilliers, S. S., L. L. Schoeman, and G. J. Bredenkamp. 1998. Wetland plant communities in the Potchefstroom municipal area, North West Province, South Africa. Bothalia 28 (2):213-229.
Cilliers, S. S., G. J. Bredenkamp, and E. van Wyk. 1999. Urban nature conservation: vegetation of natural areas in the Potchefstroom municipal area, North west province, South Africa. Koedoe 42 (1):1-30. http://dx.doi.org/10.4102/koedoe. $\underline{\mathrm{v} 42 \mathrm{i} 1.218}$

Cilliers, S. S., N. Müller, and J. E. Drewes. 2004. Overview on urban nature conservation: situation in the westerngrassland biome of South Africa. Urban Forestry and Urban Greening 3:49-62. http://dx.doi.org/10.1016/j.ufug.2004.04.003

Cilliers, S. S., N. S. G. Williams, and F. J. Barnard. 2008. Patterns of exotic plant invasions in fragmented urban and rural grasslands across continents. Landscape Ecology 23:1243-1256. http://dx.doi.org/10.1007/s10980-008-9295-7

Cilliers, S. S., J. E. Drewes, M. J. du Toit, and D. P. Cilliers. 2011. Urban ecology: policy issues resolved and unresolved. Pages 225-245 in H. S. Geyer, editor. International Handbook of Urban Policy, Volume 3: Issues in the Developing World. Edward Elgar Publishing, Cheltenham.

Cilliers, S. S., S. J. Siebert, E. Davoren, and C. S. Lubbe. 2012. Social aspects of urban ecology in developing countries, with an emphasis on urban domestic gardens. Pages 123-138 in M. Richter and U. Weiland, editors. Applied urban ecology: a global framework. Wiley-Blackwell, Chichester. http://dx.doi. org/10.1002/9781444345025.ch10

Costanza, R., R. d'Arge, R. de Groot, S. Farber, M. Grasso, B. Hannon, K. Limburg, S. Naeem, R. V. O'Neill, J. Paruelo, R. G. Raskin, P. Sutton, and M. van den Belt. 1997. The value of the world's ecosystem services and natural capital. Nature 387:253-260. http://dx.doi.org/10.1038/387253a0

Cowling, R. M., R. L. Pressey, M. Rouget, and A. T. Lombard, A. T. 2003. A conservation plan for a global biodiversity hotspot - the Cape Floristic Region, South Africa. Biological Conservation 112:191-216. http://dx.doi.org/10.1016/S0006-3207 (02)00425-1

Cowling, R. M., and R. L. Pressey. 2003. Introduction to systematic conservation planning in the Cape Florstic Region. Biological Conservation 112:1-13. http://dx.doi.org/10.1016/ S0006-3207(02)00418-4

Davies, Z. G., R. A. Fuller, A. Loram, K. Irvine, V. Sims, and K. J. Gaston. 2009. A national scale inventory of resource provision for diversity within domestic gardens. Biological Conservation 142:761-771.

Davoren, E. 2009. Patterns of plant diversity in the settlement of Ganyesa, North-West Province, South Africa. Unpublished Masters Dissertation, North-West University, Potchefstroom. URI: http://hdl.handle.net/10394/5676. 
De Wit, M. P., H. van Zyl, D. J. Crookes, J. N. Blignaut, T. Jayiya, V. Goiset and B. K. Mahumani. 2009. Investing in Natural Assets. A Business case for the Environment in the City of Cape Town. Report prepared for the City of Cape Town, Cape Town, South Africa, 18 August.

Dingaan, M. N. V., P. J. du Preez, and H. J. T. Venter. 2001. Riparian and wetland vegetation of natural open spaces in Bloemfontein, Free State. South African Journal of Botany 67 (2):294-302.

Drewes, J. E., and S. S. Cilliers. 2004. Integration of urban biotope mapping in spatial planning. Town and Regional Planning 47:15-29.

Dures, S. G., and G. S. Cumming. 2010. The confounding influence of homogenizing invasive species in a globally endangered and largely urban biome: Does habitat quality dominate avian biodiversity? Biological Conservation 143:768-777. http://dx.doi.org/10.1016/j.biocon.2009.12.019

Du Toit, M. J. 2009. Grassland ecology along an urban-rural gradient using GIS techniques in Klerksdorp, South Africa. Unpublished masters Dissertation. North-West University, Potchefstroom. URI: http://hdl.handle.net/10394/4197. http:// dx.doi.org/10.1016/j.sajb.2009.02.044

Du Toit, M. J., and S. S. Cilliers. 2011. Aspects influencing the selection of representative urbanization measures to quantify urban-rural gradients. Landscape Ecology 26:169-181. http://dx.doi.org/10.1007/s10980-010-9560-4

Egoh, B. N., B. Reyers, M. Rouget, and D. M. Richardson. 2011. Identifying priority areas for ecosystem service management in South African grasslands. Journal of Environmental Management 92(6):1642-1650. http://dx.doi.o $\mathrm{rg} / 10.1016 / \mathrm{j} . j e n v m a n .2011 .01 .019$

Fry, G., B. Tress, and G. Tress. 2007. Integrative landscape research: facts and challenges. Pages 246-268 in J. Wu and R. J. Hobbs, editors. Key topics in Landscape Ecology. Cambridge University Press, New York. http://dx.doi.org/10. $\underline{1017 / C B O 9780511618581.015}$

Gaston, K. J., R. M. Smith, K. Thompson, and P. H. Warren. 2005a. Urban domestic gardens (II): experimental tests of methods for increasing biodiversity. Biodiversity and Conservation 14:395-413. http://dx.doi.org/10.1007/s10531-0 04-6066-X

Gaston, K. J., P. H. Warren, K. Thompson, and R. M. Smith. 2005b. Urban domestic gardens (IV): The extent of the resource and its associated features. Biodiversity and Conservation 14:3327-3349. http://dx.doi.org/10.1007/s1053 1-004-9513-9

Gelderblom, C. M., B. W. Van Wilgen, J. L. Nel, T. Sandwith, M. Botha, and M. Hauck. 2003. Turning strategy into action: implementing a conservation action plan in the Cape Floristic region. Biological Conservation 112:291-297. http://dx.doi.o $\mathrm{rg} / 10.1016 / \mathrm{S} 0006-3207(02) 00399-3$

Govender, N., W. S. W. Trollope, and B. W. Van Wilgen. 2006. Effect of fire season, fire frequency, rainfall and management on fire intensity in savanna vegetation in South Africa. Journal of Applied Ecology 43(4):748-758. http://dx.d oi.org/10.1111/j.1365-2664.2006.01184.x

Graham, M., and H. Ernstson. 2012. Comanagement at the fringes: examining stakeholder perspectives at Macassar Dunes, Cape Town, South Africa - at the intersection of high biodiversity, urban poverty, and inequality. Ecology and Society 17(3):34. http://dx.doi.org/10.5751/ES-04887-170334

Grobicki, A. M. W. 2001. Urban catchment management in a developing country: the Lotus River project, Cape Town, South Africa. Water Science and Technology 44(2):313-319.

Grobler, C. H., G. J. Bredenkamp, and L. R. Brown. 2002. Natural woodland vegetation and plant species richness of the urban open spaces in Gauteng, South Africa. Koedoe 45 (1):19-34. http://dx.doi.org/10.4102/koedoe.v45i1.13

Grobler, C. H., G. J. Bredenkamp, and L. R. Brown. 2006. Primary grassland communities of urban open spaces in Gauteng, South Africa. South African Journal of Botany 72:367-377. http://dx.doi.org/10.1016/j.sajb.2005.10.008

Hahs, A. K., and M. J. McDonnell. 2006. Selecting independent measures to quantify Melbourne's urban-rural gradient. Landscape and Urban Planning 78:435-448. http:// dx.doi.org/10.1016/j.landurbplan.2005.12.005

Hahs, A. K., M. J. McDonnell, and J. H. Breuste. 2009a. A comparative ecology of cities and towns: synthesis of opportunities and limitations. Pages 574-596 in M. J. McDonnell, A. K. Hahs, and J. Breuste, editors. Ecology of cities and towns, a comparative approach. Cambridge University Press, New York.

Hahs, A. K., M. J. McDonnell, M. K. McCarthy, P. A. Vesk, R. T. Corlett, B. A. Norton, S. E. Clemants, R. P. Duncan, K. Thompson, M. W. Schwartz, and N. S. G. Williams. $2009 b$. A global synthesis of plant extinction rates in urban areas. Ecology Letters 12:1165-1173. http://dx.doi.org/10.1111/j.14 61-0248.2009.01372.x

Hoffman, T. S. and M. Justin O'Riain. 2012. Monkey management: using spatial ecology to understand the extent and severity of human-baboon conflict in the Cape Peninsula, South Africa. Ecology and Society 17(3):13. http://dx.doi.org $\underline{10.5751 / \text { ES-04882-170313 }}$

Holmes, P. M., A. G. Rebelo, C. Dorse, and J. Wood. 2012. Can Cape Town's unique biodiversity be saved? Balancing 
conservation imperatives and development needs. Ecology and Society 17(2):28. http://dx.doi.org/10.5751/ES-04552-170228

Janse van Rensburg, J. P. 2010. Investigation of the microbial diversity and functionality of soil in fragmented South African grasslands along an urbanization gradient. Unpublished Masters Dissertation, North-West University, Potchefstroom.

Jonas, R. 2007. Epigeal arthropods along an urbanization gradient in Potchefstroom. Unpublished Masters Dissertation, North-West University, Potchefstroom. URI: http://hdl. handle.net/10394/1071.

Knight, A. T., A. Driver, R. M. Cowling, K. Maze, P. G. Desmet, A. T. Lombard, M. Rouget, M. A. Botha, A. F. Boshoff, J. G. Castley, P. S. Goodman, K. MacKinnon, S. M. Pierce, R. Sims-Castley, W. I. Stewart, and A. Von Hase. 2006. Designing systematic conservation assessments that promote effective implementation: best practice from South Africa. Conservation Biology 20(3):739-750. http://dx.doi.org/10.1111/ j.1523-1739.2006.00452.x

Knight, A. T., R. M. Cowling, M. Rouget, A. Balmford, A. T. Lombard, and B. M. Campbell. 2008. Knowing but not doing: Selecting priority conservation areas and the researchimplementation gap. Conservation Biology 22:610-617. http: //dx.doi.org/10.1111/j.1523-1739.2008.00914.x

Kuruneri-Chitepo, C., and C. M. Shackleton. 2011. The distribution, abundance and composition of street trees in selected towns of the Eastern Cape, South Africa. Urban Forestry and Urban Greening 10:247-254. http://dx.doi.org/1 0.1016/j.ufug.2011.06.001

Lubbe, C. S. 2011. Comparison of the urban domestic garden flora along a socioeconomic gradient in Potchefstroom. Unpublished Masters Dissertation, North-West University, Potchefstroom.

Lubbe, C. S., S. J. Siebert, and S. S. Cilliers. 2010. Political legacy of South Africa affects the plant diversity patterns of urban domestic gardens along a socio-economic gradient. Scientific Research and Essays 5(19):2900-2910.

Lubbe, C. S., S. J. Siebert, and S. S. Cilliers. 2011. Floristic analysis of domestic gardens in the Tlokwe City Municipality, South Africa. Bothalia 41(2):351-361.

Marzluff, J. M., E. Shulenberger, W. Endlicher, M. Alberti, G. Bradley, C. Ryan, U. Simon, and C. ZumBrunnen. editors. 2008. Urban ecology - an international perspective on the interaction between humans and nature. Springer, New York.

Mathieu, R., C. Freeman, and J. Aryal. 2007. Mapping private gardens in urban areas using object-oriented techniques and very high -resolution satellite imagery. Landscape and Urban Planning 81:179-192. http://dx.doi.org/10.1016/j.landurbplan $\underline{.2006 .11 .009}$

McConnachie, M. M. and C. M. Shackleton. 2010. Public green space inequality in small towns in South Africa. Habitat International 34:244-248. http://dx.doi.org/10.1016/j.habitati $\underline{\text { nt.2009.09.009 }}$

McConnachie, M. M., C. M. Shackleton, and G. K. McGregor. 2008. The extent of public green space and alien plant species in 10 small towns of the Sub-Tropical thicket biome, South Africa. Urban Forestry and Urban Greening 7:1-13. http://dx .doi.org/10.1016/j.ufug.2007.12.003

McDonnell, M. J. 2011. The History of Urban Ecology - An Ecologist's Perspective. Pages 5-13 in J. Niëmela, J. Breuste, T. Elmqvist, G. Guntenspergen, P. James and N. E. McIntyre, editors. Urban ecology: Patterns, Processes and Applications. Oxford University Press, Oxford.

McDonnell, M. J., and S. T. A. Pickett. 1990. Ecosystem structure and function along urban-rural gradients: an unexploited opportunity for ecology. Ecology 71 (4):1232-1237. http://dx.doi.org/10.2307/1938259

McKinney, M. L., and J. L. Lockwood. 1999. Biotic homogenizaton: a few winners replacing many losers in the next mass extinction. Trends in Ecology and Evolution 14:450-453. http://dx.doi.org/10.1016/S0169-5347(99)01679-1

Molebatsi, L. 2011. An assessment of the useful plant diversity in homegardens and communal land of Tlhakgameng, NorthWest. Unpublished Masters Dissertation, North-West University, Potchefstroom.

Molebatsi, L., S. J. Siebert, S. S. Cilliers, C. S. Lubbe, and E. Davoren. 2010. The Tswana tshimo: A homegarden system of useful plants with a particular layout and function. African Journal of Agricultural Research 5(21):2952-2963.

O'Farrell, P. J., P. M. L. Anderson, D. C. Le Maitre, and P. M. Holmes. 2012. Insights and opportunities offered by a rapid ecosystem service assessment in promoting a conservation agenda in an urban biodiversity hotspot. Ecology and Society 17(3): 27. http://dx.doi.org/10.5751/ES-04886-170327

Pauw, A., and K. Louw. 2012. Urbanization drives a reduction in functional diversity in a guild of nectar-feeding birds. Ecology and Society 17(2):27. http://dx.doi.org/10.5751/ES-0 4758-170227

Petersen, L. M., E. J. Moll, R. Collins, and M. T. Hockings. 2012. Development of a compendium of local, wild-harvested species used in the informal economy trade, Cape Town, South Africa. Ecology and Society 17(2):26. http://dx.doi.org/10.5751/ ES-04537-170226 
Pollard, S., H. Biggs, and D. Du Toit. 2008. Towards a socialecological systems view of the Sand River Catchment. South Africa: A resilience analysis of the socio-ecological system. Water Research Commision (WRC) South Africa Report No TT 364/08.

Poynton, J. C., and D. C. Roberts. 1985. Urban open space planning in South Africa: a biogeographical perspective. South African Journal of Science 81:33-37.

Pryke, J. S., and M. J. Samways. 2009. Recovery of invertebrate diversity in a rehabilitated city landscape mosaic in the heart of a biodiversity hotspot. Landscape and Urban Planning 93:54-62. http://dx.doi.org/10.1016/j.landurbplan.2 $\underline{009.06 .003}$

Rebelo, A. G., P. M. Holmes, C. Dorse, and J. Wood. 2011. Impacts of urbanization in a biodiversity hotspot: conservation challenges in Metropolitan Cape Town. South African Journal of Botany 77:20-35. http://dx.doi.org/10.1016/j.sajb.2010.04.006

Ridd, M. K. 1995. Exploring a V-I-S (Vegetation, Impervious surface, Soil) model for urban ecosystem analysis through remote sensing: comparative anatomy for cities. International Journal of Remote Sensing 16(12):2165-2185. http://dx.doi.o $\mathrm{rg} / 10.1080 / 01431169508954549$

Roberts, D. C. 1993. The vegetation ecology of municipal Durban. Floristic classification. Bothalia 23(2):271-326.

Roberts, D. C. 2001. Using the development of an environmental management system to develop and promote a more holistic understanding of urban ecosystems in Durban, South Africa. Pages 384-398 in A. R. Berkowitz, C. H. Nilon and $\mathrm{K}$. Hollweg, editors. Urban Ecosystems, a new frontier for science and education. Springer, New York. http://dx.doi. org/10.1007/0-387-22615-X_24

Roberts, D. C. 2008. Thinking globally, acting locally institutionalizing climate change at the local government level in Durban, South Africa. Environment \& Urbanization 20 (2):521-537. http://dx.doi.org/10.1177/0956247808096126

Roberts, D. C. 2010. Prioritizing climate change adaptation and local level resilience in Durban, South Africa. Environment \& Urbanization 22(2):397-413.

Roberts, D. C., and N. Diederichs. 2002. Durban's Local Agenda 21 programme: tackling sustainable development in a post-apartheid city. Environment \& Urbanization 14 (1):189-201.

Roberts, D. C., R. Boon, P. Croucamp, and M. Mander. 2005. Resource economics as a tool for open space planning in Durban, South Africa. Pages 44-48 in T. Tryzna, editor. The Urban Imperative, urban outreach strategies for protected areas agencies. California Institute of Public Affairs, Sacramento.
Roberts, D. C., R. Boon, N. Diederichs, E. Douwes, N. Govender, A. McInnes, C. McLean, S. O'Donoghue, and M. Spires. 2011. Exploring ecosystem-based adaptation in Durban, South Africa: "learning-by-doing" at the local government coal face. Environment \& Urbanization 24 (1):1-29.

Robinson, N. A. (editor). 1993. Agenda 21: Earth's Action Plan. IUCN environmental policy and law paper no.027. Oceana Publications. New York, New York. U.S.A.

Rouget, M., D. M. Richardson, and R. M. Cowling. 2003. The current configuration of protected areas in the Cape Floristic Region, South Africa - reservation bias and representation of biodiversity patterns and processes. Biological Conservation 112:129-145. http://dx.doi.org/10.1016/S0006-3207(02)00396-8

Savard, J. L., P. Clergeau, and G. Mennechez. 2000. Biodiversity concepts and urban ecosystems. Landscape and Urban Planning 48:131-142. http://dx.doi.org/10.1016/S0169 $\underline{-2046(00) 00037-2}$

Seppings, K., J. Cooke, and D. C. Roberts. 1995. The openspace system of Durban and challenges to urban conservation in the new South Africa. Land Contamination and Reclamation 3:1-10.

Smith, R. M., P. H. Warren, K. Thompson, and K. J. Gaston. 2006a. Urban domestic gardens (VI): Environmental correlates on invertebrate species richness. Biodiversity and Conservation 15:2415-2438. http://dx.doi.org/10.1007/s1053 $\underline{1-004-5014-0}$

Smith, R. M., K. J. Gaston, P. H. Warren, and K. Thompson. 2006b. Urban domestic gardens (VIII): Environmental correlates on invertebrate abundance. Biodiversity and Conservation 15:2515-2545. http://dx.doi.org/10.1007/s1053 1-005-2784-y

Sukopp, H. 1998. Urban Ecology - scientific and practical aspects. Pages 3-16 in J. Breuste, H. Feldmann and O. Uhlmann, editors. Urban Ecology. Springer, Berlin, Springer.

Sukopp, H., and S. Weiler. 1988. Biotope mapping and nature conservation strategies in urban areas in the Federal Republic of Germany. Landscape and Urban Planning 15:39-58. http: //dx.doi.org/10.1016/0169-2046(88)90015-1

TEEB (The Economics of Ecosystems and Biodiversity). 2011. TEEB Manual for Cities - Ecosystem services in urban management. Available at: www.teebweb.org

Tennent, J., and C. T. Downs. 2008. Abundance and home ranges of feral cats in an urban conservancy where there is supplemental feeding: a case study from South Africa. African Zoology 43(2):218-229. http://dx.doi.org/10.3377/1562-7020 $\underline{-43.2 .218}$ 
Van Rensburg, B., D. S. Peacock, and M. P. Robertson. 2009. Biotic homogenization and alien bird species along an urban gradient in South Africa. Landscape and Urban Planning 92:233-241. http://dx.doi.org/10.1016/j.landurbplan.2009.05.002

Van Wilgen, B. W. 2012. Evidence, perceptions, and tradeoffs associated with invasive alien plant control in the Table Mountain National Park, South Africa. Ecology and Society 17(2):23. http://dx.doi.org/10.5751/ES-04590-170223

van Wilgen, B. W., G. G. Forsyth, and P. Prins. 2012. The management of fire-adapted ecosystems in an urban setting: the case of Table Mountain National Park, South Africa. Ecology and Society 17(1):8. http://dx.doi.org/10.5751/ES-04 $\underline{526-170108}$

Wilken, M. E. C. 2007. Urban biotope mapping as framework for spatial planning in Mbombela Municipality, Mpumalanga, South Africa. Unpublished Masters Dissertation, North-West University, Potchefstroom.

Wu, J. 2008. Making the case for Landscape Ecology: an effective approach to urban sustainability. Landscape Journal 27:41-50. http://dx.doi.org/10.3368/lj.27.1.41

Younge, A., and S. Fowkes. 2003. The Cape Action Plan for the environment: overview of an ecoregional planning process. Biological Conservation 112:15-28. http://dx.doi.org 110.1016/S0006-3207(02)00393-2

Zipperer, W. C., W. C. Morse, and C. J. Gaither. 2011. Linking social and ecological systems. Pages 298-308 in J. Niëmela, J. Breuste, T. Elmqvist, G. Guntenspergen, P. James and N. E. McIntyre, editors. Urban ecology: Patterns, Processes and Applications. Oxford University Press, Oxford. 